\title{
Analysis on Local Stress of Steel-concrete Joint Section of Weihe Grand Bridge

\author{
Weiwei Chen ${ }^{1, a}$, Bin Liang ${ }^{1, b}$ and Wenjing Wang ${ }^{1, c}$
}

Civil Engineering School, Henan University of Science and Technology, Luoyang 471023, China

a1278216732@qq.com, bliangbin4231@163.com, ${ }^{\mathrm{a}} 742094540 @ q q . c o m$

Keywords: steel-concrete joint section; finite element method; stress;

Abstract. Local stress of steel-concrete joint section is analyzed in the role of three conditions. According to the engineering example of Weihe grand bridge, the finite element space model of steel-concrete joint section is built. Through calculation and analysis, the stress state of steel-concrete joint section is analyzed under three load conditions. The results show that stresses meet all the requirements of design except that the stress concentration occurs at the bottom of concrete box beam by the side of the bearing plate and at the area prestressed tendon anchored. And part of tensile stress exceeds tensile strength of concrete at corner of concrete box beam floor and roof. With continuous and coordinated deformation, the design of steel-concrete joint section is safe and reliable, realizing the smooth transition of stiffness. Considering the complex stress of steel-concrete joint section, it is proposed to add proper tensile fiber in the concrete in steel-concrete joint section to improve performance of structure.

\section{Introduction}

Steel-concrete composite beam is a hybrid structure system connecting concrete beam and steel beam into a whole by joint section in the appropriate vertical position [1]. There are several methods to research the stress performance of steel-concrete joint section like indoor scale-down model test, entity engineering field test and finite element numerical and analysis test $[2,3]$. The finite element method can well simulate the real structure condition and various using conditions at the same time $[4,5]$.

The safety and reasonable design is verified by using the finite element numerical analysis method to establish space finite element model of structural unit of steel-concrete joint section, considering three conditions to analyze and calculate the local stress.

\section{Project Profile}

Weihe grand bridge, which upper structure is variable cross-section prestressed concrete continuous box beam and prestressed concrete continuous rigid frame, is a super large bridge in Xitong highway across Wei River. Among it, the ratio of the side span and middle span at the last span in the first joint variable cross-section prestressed concrete continuous box beam reaches 1:1. If still using prestressed concrete box beam, the structure will be difficult to meet the specification requirements. So the $53.68 \mathrm{~m}$ steel box beam has been set in the last span to reduce weight. And the steel-concrete joint section has been set between the two box beam where the shearing force and the bending moment is small to construct the steel-concrete continuous box beam. The location also considers three facts: reasonable force, convenient construction and cost the economy. The structure of steel-concrete joint section is shown in Fig.1. 


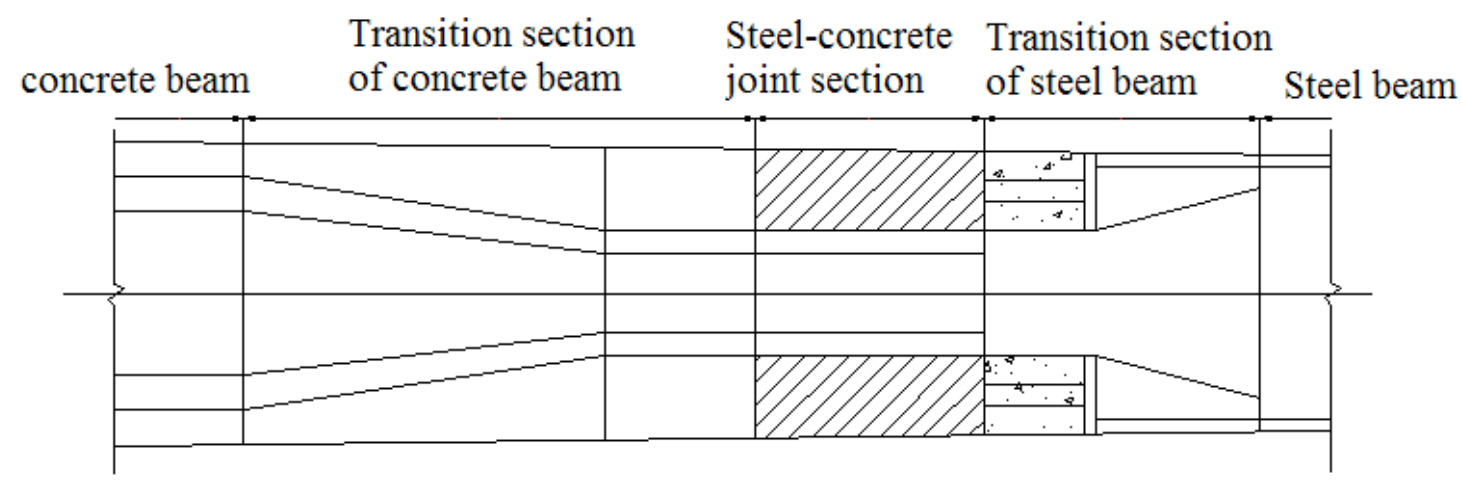

Fig. 1 Structural of steel-concrete joint section

\section{Finite Element analytical model}

The model established in ANSYS finite element software intercepts $21 \mathrm{~m}$ in total length of beam section, including $11 \mathrm{~m}$ transition section of concrete box beam, $2.5 \mathrm{~m}$ of steel-concrete joint section, $2.5 \mathrm{~m}$ stiffness transition section of steel box beam and $5 \mathrm{~m}$ steel box beam. Solid 45 element is used to simulate concrete member, Shell181 element is used to simulate steel member and Link8 element is used to simulate prestressing tendon. In the model, Z-axis indicates the span direction, Y-axis indicates the vertical direction, $\mathrm{X}$-axis indicates the transverse direction of the bridge. The whole model of simplified steel-concrete joint section is shown in Fig.2. Fig.3 shows the steel box beam.

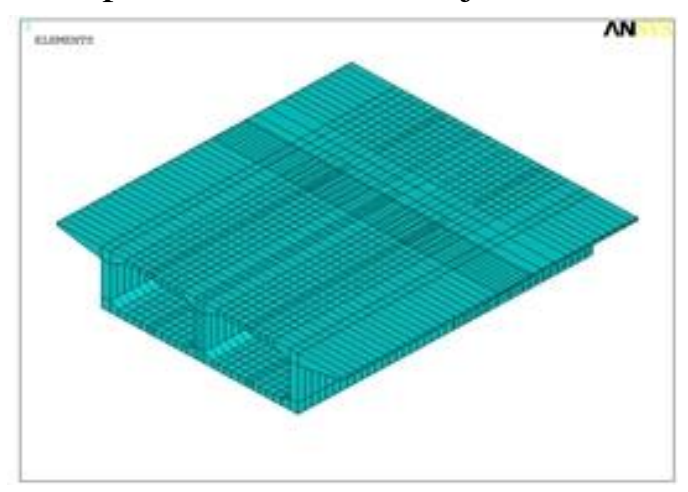

Fig.2 Total finite element model of

\section{steel-concrete joint section}

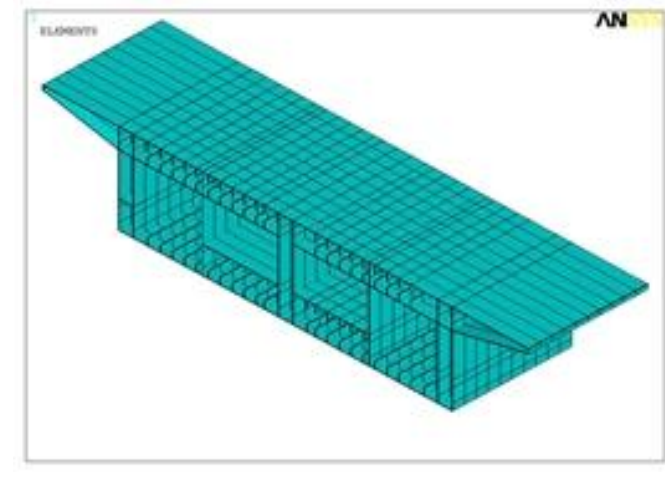

Following is simulation boundary conditions. Finite element model uses cantilever loading way. Faced the side of the concrete box girder, the rigid zone is established by the boundary of steel box beam in order to achieve the coordinated deformation of steel box beam of boundary nodes, meeting the plane section assumption.

\section{Calculation loads and conditions}

Calculation loads of steel-concrete joint section model include steel beam end section load (axial force, vertical force and bending moment), secondary dead load and moving load. Three kinds of calculation conditions are considered in the model.

Condition I : normal use limit state function of long-term effect combination.

Condition II : design limit load effect combination.

Condition III: 1.7 times design limit load effect combination. 


\section{Calculation Results and Analysis}

Stress performance of steel-concrete joint section is reacted by the stress of steel member and concrete member of the joint section.

\begin{tabular}{|c|c|c|c|c|c|}
\hline \multirow{8}{*}{ Condition I } & \multirow{2}{*}{\multicolumn{3}{|c|}{ item }} & \multicolumn{2}{|c|}{ Steel-concrete joint section } \\
\hline & & & & \multirow{2}{*}{$\begin{array}{c}\begin{array}{c}\text { Concrete } \\
\text { member }\end{array} \\
-0.57 \\
\end{array}$} & \multirow{2}{*}{$\begin{array}{c}\begin{array}{c}\text { Steel } \\
\text { member }\end{array} \\
-0.661 \\
\end{array}$} \\
\hline & \multirow{4}{*}{$\begin{array}{c}\text { Princip } \\
\text { al stress } \\
(\mathrm{MPa} \\
)\end{array}$} & \multirow{2}{*}{$\sigma_{1}$} & Min & & \\
\hline & & & $\operatorname{Max}$ & 0.672 & 0.055 \\
\hline & & \multirow{2}{*}{$\sigma_{3}$} & Min & -1.79 & -17.6 \\
\hline & & & Max & -16.1 & -1.95 \\
\hline & \multirow{2}{*}{\multicolumn{2}{|c|}{$\mathrm{Z}$ stress $(\mathrm{MPa})$}} & Min & -0.619 & -17.6 \\
\hline & & & Max & 0.647 & 16.0 \\
\hline
\end{tabular}

Table 1 The principal stress and $Z$ stress of each member in condition I

Note: $\sigma_{1}$ is the first principal stress, $\sigma_{3}$ is the third principal stress and $\mathbf{Z}$ stress is positive stress along $Z$ axis. Plus is the tensile stress and minus is the compressive stress.

It can be seen from Tab.1, under normal use limit state function of long-term effect combination, the third principal stress of the concrete member is in the range of $-1.79 \sim-16.1 \mathrm{MPa}$. The stress concentration phenomenon appears in the anchorage of prestressed reinforcement which has no impact on the overall stress by the solution of local strengthened anchorage zone. The maximum Mises stress of the steel member is $61.0 \mathrm{MPa}$.

\begin{tabular}{|c|c|c|c|c|c|}
\hline \multirow{8}{*}{ Condition II } & \multirow{2}{*}{\multicolumn{3}{|c|}{ item }} & \multicolumn{2}{|c|}{ Steel-concrete joint section } \\
\hline & & & & \multirow{2}{*}{$\begin{array}{c}\begin{array}{c}\text { Concrete } \\
\text { member }\end{array} \\
-0.137\end{array}$} & \multirow{2}{*}{$\begin{array}{c}\begin{array}{c}\text { Steel } \\
\text { member }\end{array} \\
4.16\end{array}$} \\
\hline & \multirow{4}{*}{$\begin{array}{c}\text { Princip } \\
\text { al stress } \\
(\mathrm{MPa} \\
)\end{array}$} & \multirow{2}{*}{$\sigma_{1}$} & Min & & \\
\hline & & & Max & 2.28 & 37.4 \\
\hline & & \multirow{2}{*}{$\sigma_{3}$} & Min & -1.14 & -26.0 \\
\hline & & & Max & 0.267 & -2.89 \\
\hline & \multirow{2}{*}{\multicolumn{2}{|c|}{$\mathrm{Z}$ stress（MPa） }} & Min & -0.945 & -24.3 \\
\hline & & & $\operatorname{Max}$ & 2.21 & 35.2 \\
\hline
\end{tabular}

Tab.2 The principal stress and $\mathrm{Z}$ stress of each member in Condition II

In Tab.2, the first principal stress of the concrete member is range from $-0.137 \sim 2.28 \mathrm{MPa}$ under design limit load effect combination. The maximum principal tensile stress arise at the bottom of concrete box beam by the side of the bearing plate. $\mathrm{Z}$ stress of concrete member is in the $-0.945 \sim 2.21 \mathrm{MPa}$. The maximum Mises stress of the steel member is $78.3 \mathrm{MPa}$, far less than the allowable design stress of Q345 steel (295MPa). 


\begin{tabular}{|c|c|c|c|c|c|}
\hline \multirow{8}{*}{ Condition III } & \multirow{2}{*}{\multicolumn{3}{|c|}{ item }} & \multicolumn{2}{|c|}{$\begin{array}{c}\text { Steel-concrete beam linked } \\
\text { park }\end{array}$} \\
\hline & & & & \multirow{2}{*}{$\begin{array}{c}\begin{array}{c}\text { Concrete } \\
\text { member }\end{array} \\
-1.37 \\
\end{array}$} & \multirow{2}{*}{$\begin{array}{c}\begin{array}{c}\text { Steel } \\
\text { member }\end{array} \\
2.93 \\
\end{array}$} \\
\hline & \multirow{4}{*}{$\begin{array}{c}\text { Princip } \\
\text { al stress } \\
(\mathrm{MPa} \\
)\end{array}$} & \multirow{2}{*}{$\sigma_{1}$} & Min & & \\
\hline & & & Max & 9.35 & 26.4 \\
\hline & & \multirow{2}{*}{$\sigma_{3}$} & Min & -6.93 & -21.3 \\
\hline & & & Max & 0.439 & -2.36 \\
\hline & \multirow{2}{*}{\multicolumn{2}{|c|}{$\mathrm{Z}$ stress $(\mathrm{MPa})$}} & Min & -6.53 & -20.9 \\
\hline & & & Max & 9.32 & 26.3 \\
\hline
\end{tabular}

Tab.3 The principal stress and $\mathrm{Z}$ stress of each member in Condition III

Tab. 3 shows that under 1.7 times design limit load effect combination, the overall stress level of each member increase. The maximum Mises stress of the steel member is 108MPa. The first principal stress of the concrete member is range from $-1.37 \sim 9.35 \mathrm{MPa}$. A small part of the concrete exceeds the C55 concrete tensile strength design value. This part mainly appears at corner of concrete box beam floor and roof of steel-concrete joint section. It can eliminate stress concentration by certain structural measures to meet the requirements. In brief, under 1.7 times design limit load effect combination, steel-concrete joint section is still safe.

\section{Conclusions}

Under the effect of three conditions, Mises stress of the steel members are all less than the allowable design stress of Q345 steel (295MPa). When 1.7 times design limit load combination effects, the maximum tensile stress in a small part of the concrete exceeds the C55 concrete tensile strength design value of $1.96 \mathrm{MPa}$ which mainly appears at corner of concrete box beam floor and roof of steel-concrete joint section. It can improve the structure stress state by adding proper tensile fiber to the concrete and paying attention to structural treatment to prevent concrete cracking. The maximum principal compressive stress of concrete appearing in the anchorage of prestressed reinforcement is less than the design value of concrete compressive strength of 25.3MPa.

Generally speaking, in the role of three conditions, the stress of steel-concrete joint section is quite balanced and the deformation is continuous and coordinated. The overall stress level generally meet the design requirements that illustrates the design of steel-concrete joint section is safe and reliable, having realized the smooth transition of stiffness.

\section{References}

[1] X.H. Ying, Y.F. Wang, Study on steel-concrete joint of hybrid girder bridge, J. Journal of Railway Engineering Society. 7 (2012) 29-32. (in Chinese)

[2] J. He, Y.Q. Liu, Pei, B. Zhi, Experimental study of the steel-concrete connection in hybrid cable-stayed bridges, J. Journal of Performance of Constructed Facilities. 3 (2014) 559-570.

[3] Q.Z. Zhang, B.S. Wu, Model test study of steel and concrete joint section of Jiujiang Changjiang river highway bridge, J. Bridge Construction. 5 (2013) 68-74. (in Chinese)

[4] J.F. Zhang, X.Z. Li, L. Xiao, Y.W. Bao, Numerical simulation analysis of steel-concrete joint section in hybrid girder of cable-stayed bridge, J. Journal of Southwest Jiaotong University. 4 (2014) 619-625. (in Chinese) 
[5] X.Z. Li, L. Xiao, X.B. Su, X. Wei, Mechanical properties of steel-concrete composite section in space rigid frame, J. Journal of Southwest Jiaotong University. 6 (2012) 907-914. (in Chinese) 